\title{
Antinociceptive Action of Moringa peregrina is Mediated by an Interaction with $\alpha_{2}$-Adrenergic Receptor
}

\author{
Sahar M. Jaffal1, Belal O. Al-Najjar2, Manal A. Abbas³, Sawsan A. Oran1 \\ ${ }^{1}$ Department of Biological Sciences, Jordan University School of Science, Amman, Jordan \\ ${ }^{2}$ Department of Pharmaceutical Sciences, Al-Ahliyya Amman University School of Pharmacy, Amman, Jordan \\ ${ }^{3}$ Department of Medical Laboratory Sciences, School of Allied Medical Sciences, Al-Ahliyya Amman University, Amman, Jordan
}

Background: Moringa peregrina (M. peregrina) is an edible, drought-resistant tree that is native to semi-arid countries. It is used as a painkiller in folk medicine.

Aims: To study the antinociceptive effects of the leaf extract of M. peregrina in mice.

Study Design: Animal experimentation.

Methods: We employed thermal (hot plate and tail-immersion tests) and chemical (writhing and formalin tests) pain models in male $\mathrm{BALB} / \mathrm{c}$ mice (eight animals per group) to investigate the mechanisms involved in the antinociceptive actions of $M$. peregrina. Additionally, we identified the chemical constituents present in the extract of M. peregrina by using liquid chromatography-mass spectrometry analysis, and predicted the possible active constituents that interact with the receptor based on molecular docking simulations.

Results: In the writhing test, $200 \mathrm{mg} / \mathrm{kg}$ of $M$. peregrina extract restricted abdominal cramps by up to $55.97 \%(\mathrm{p}<0.001)$. Further, it reduced the time of paw-licking in the early and late phases of formalin test by up to $56.8 \%$ and $65.5 \%$, respectively, as compared to the percentage inhibitions of $50.5 \%$ and $48.4 \%$ produced by $30 \mathrm{mg} / \mathrm{kg}$ diclofenac sodium in the early and late phases, respectively $(\mathrm{p}<0.05)$. This effect was abrogated by yohimbine ( $1 \mathrm{mg} / \mathrm{kg}$, intraperitoneally), but not by methysergide ( $5 \mathrm{mg} / \mathrm{kg}$, intraperitoneally), in the late phase only, which indicates that the action of M. peregrina in formalin test is not mediated by 5-HT2 serotonin receptors, but rather via $\alpha_{2}$ adrenergic receptors. In the hot plate test, but not on tail-immersion test, the high dose $(400 \mathrm{mg} / \mathrm{kg})$ of the extract increased the latency time after 30 minutes of its administration. Yohimbine antagonized the action of M. peregrina in the hot plate test. Based on LC-MS analysis, the major constituents found in M. peregrina methanolic extract were chrysoeriol 7-O-diglucoside, lupeol acetate, quercetin, and rutin. Depending on the molecular docking results, the activity of $M$. peregrina extract could be due to the binding of chrysoeriol 7-O-diglucoside, quercetin, and rutin to the $\alpha_{2}$-adrenergic receptor.

Conclusion: Interaction with the $\alpha_{2}$-adrenergic receptor serves as a possible mechanism of the M. peregrina analgesic effect.

Keywords: Adrenergic alpha-2 receptor antagonists, analgesics, molecular docking, Moringa peregrina
Moringa (Moringaceae) is a genus that comprises 13 species of trees and shrubs growing in the tropical and sub-tropical regions of our world (1). Various civilizations, such as Greek, Indian, and Egyptian, have utilized Moringa for many millennia. Moringa (mainly its leaves and fruits) has always been an integral part of people's diet. Additionally, Moringa leaves were fed to the ancient Mauryan warriors of India to provide them with energy and relieve their pain (2). Moringa peregrina (M. peregrina) is a drought-resistant tree that grows in the dry or semi-arid countries located near the Red Sea such as Somalia, Syria, Palestine, and Yemen (3). The tree is known for its fast growth and can reach up to 3-10 meters in height after ten months of its cultivation (4). The leaves of $M$. peregrina are obovate, alternate, deciduous, and about $30-40 \mathrm{~cm}$ in length (2). Almost all parts of this plant are consumed by humans as a vegetable due to its taste, flavor, and nutritional value. The leaves of $M$. peregrina are great sources of proteins, vital elements $\left(\mathrm{Ca}^{+2}, \mathrm{Mg}^{+2}, \mathrm{~K}^{+1}\right.$ and $\left.\mathrm{Fe}^{+2}\right)$, essential amino acids, and vitamins such as vitamin A, C, and E $(5,6)$. $M$. peregrina is considerably used by people of various cultures in traditional healing practices during childbirth and for treating multiple disorders, such as malaria, fever, diabetes, abdominal pain, asthma, headache, constipation, muscle pain, hypertension, burns $(7,8)$. Pharmacological studies have reported that $M$. peregrina has antimicrobial (9), in vitro antioxidant (8), anticancer (10), and antispasmodic properties (7) as well as immunomodulatory activities (both ex vivo and in vivo) (3). In rats, M. peregrina has demonstrated anti-inflammatory (11), antiulcer (12), antihyperglycemic (13), antihyperlipidemic (14), antihypertensive effects (15), and memoryenhancing activities (16).

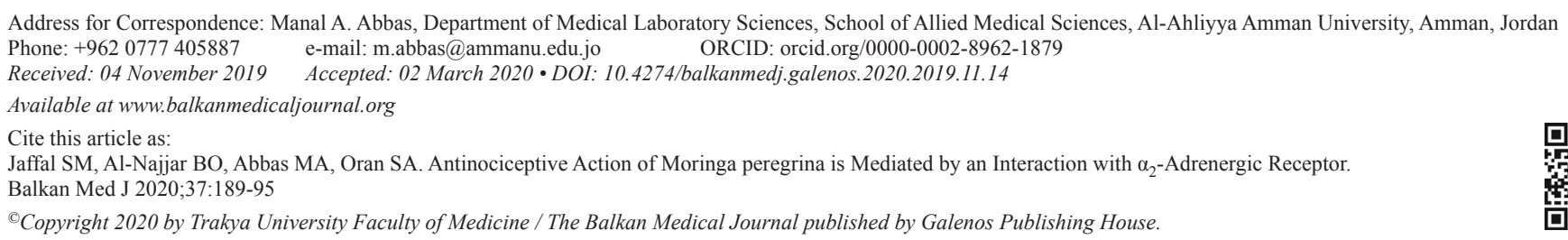


Despite the use of $M$. peregrina in folk medicine as a painkiller (4), there is a paucity of detailed studies determining the analgesic effects of this plant. Previous work on $M$. peregrina includes only a preliminary investigation that employed writhing and hot plate tests (12). The purpose of this investigative study is to examine the effects of $M$. peregrina on the early and late phases of formalin test. Additionally, we performed tail-immersion test to study the effects of $M$. peregrina at the spinal level. Furthermore, we studied the mechanism by which $M$. peregrina exerts its action.

\section{MATERIALS AND METHODS}

\section{Drugs}

Diclofenac sodium was obtained from Novartis, Switzerland, whereas methysergide was obtained from Sigma-Aldrich, USA. Yohimbine was purchased from Tocris Bioscience (UK). All the drugs were freshly prepared in a sterile normal saline solution and administered intraperitoneally (i.p).

\section{Collection of plant material}

The leaves of M. peregrina were collected in June 2012 from Wadi Bin-Hammad Valley (Karak, south of Jordan). Professor Sawsan Oran, plant taxonomist at the University of Jordan, authenticated the leaves.

\section{Preparation of plant extract}

The dried leaves of $M$. peregrina were extracted by maceration in 96\% methanol (Scharlau Chemie, Spain). Rotary evaporator was used to evaporate methanol under reduced pressure and at a temperature not more than $45^{\circ} \mathrm{C}$. The extract was stored at $-20^{\circ} \mathrm{C}$, and it was freshly prepared, before its use, by dissolving it in the sterile normal saline solution.

\section{Experimental animals}

All employed procedures in this study complied with the guidelines of the International Association for the Study of Pain (17) and were approved by the ethical committee at Al-Ahliyya Amman University (ethical approval no. AAU-2/4/2018). Male BALB/c mice (weight: $20-25 \mathrm{~g}$ ) were kept at standard laboratory conditions (at $23 \pm 2^{\circ} \mathrm{C}$ in both dark and light environments consecutively). Food and water were provided ad libitum. The animals were allowed to acclimatize to the experimental laboratory conditions for 120 minutes before the commencement of experiments.

\section{Pretreatment of animals}

In all the experiments, animals were pretreated i.p with $10 \mathrm{~mL} /$ $\mathrm{kg}$ vehicle (sterile normal saline solution, control) along with 200 $\mathrm{mg} / \mathrm{kg}$ or $400 \mathrm{mg} / \mathrm{kg} \mathrm{M}$. peregrina methanolic extract 30 minutes before the commencement of the experiments. Diclofenac sodium $(30 \mathrm{mg} / \mathrm{kg}$ ) was used as a standard drug similar to the research of Jaffal and Abbas (18). Methysergide (5 mg/kg) or yohimbine $(1 \mathrm{mg} / \mathrm{kg}$ ) was injected 15 minutes before the administration of a fixed dose of $M$. peregrina extract $(200 \mathrm{mg} / \mathrm{kg}$ or $400 \mathrm{mg} / \mathrm{kg}$ ). The choice of doses of antagonists was based on the previously published studies $(19,20)$.

\section{Writhing test}

Writhing test was conducted, as per Koster method (21), via the administration of acetic acid solution $(1 \%, 10 \mathrm{~mL} / \mathrm{kg})$ i.p in the animals 30 minutes after receiving the vehicle solution, $M$. peregrina extract $(200 \mathrm{mg} / \mathrm{kg}$ or $400 \mathrm{mg} / \mathrm{kg})$, or diclofenac sodium. Each group consisted of eight animals (mice). After 10 minutes of acetic acid administration, the number of writhes was counted for 20 minutes. A writhe is considered as a contraction of the abdominal muscles accompanied by the elongation of the body and extension of the forelimbs. The percentage inhibition of abdominal cramps was calculated by using the following formula:

$\%$ inhibition $=$ Average number of writhes in control - Average number of writhes in treated animals $\times 100 \%$

Average number of writhes in control.

\section{Paw-licking test}

Paw-licking test was performed after the intraplantar administration of $2.5 \%$ formalin $(20 \mu \mathrm{L})$ to the left hind paw of the mouse. The total time spent in licking the injected paw, lifting the leg, or exhibiting a flinching behavior were recorded in the first 5 minutes after the administration of formalin (early phase) and during the late phase (25-30 minutes after injection). The percentage inhibition was calculated according to the following formula:

$\%$ inhibition $=\underline{\text { Average time of licking in control - average time of }}$ licking in treated animals $\times 100 \%$

Average time of licking_in control

\section{Hot plate test}

The hot plate test was used to determine latencies in pain reaction. Mice reactions were assessed by individually placing the animals into a transparent container on a hot plate at $55 \pm 1^{\circ} \mathrm{C}$. Each mouse underwent this procedure only once. The time between the animal's placement and first jump was recorded as a measure for the latency of pain reaction. A cut-off time of 60 seconds was determined to avoid tissue damage.

\section{Tail-immersion test}

Tail-immersion test was performed by dipping the tail in water at $55 \pm 1^{\circ} \mathrm{C}$. The time starting from immersing the tail in water till the appearance of the first flick was calculated. A cut-off time of 10 seconds was determined.

\section{Liquid chromatography-mass spectrometry (LC-MS)}

LC-MS separation was performed in the mobile phase. This phase have solvents $\mathrm{A}$ and $\mathrm{B}$ in gradient, in which $\mathrm{A}$ contained $0.1 \%$ $(\mathrm{v} / \mathrm{v})$ formic acid in water and $\mathrm{B}$ had $0.1 \%(\mathrm{v} / \mathrm{v})$ formic acid in acetonitrile. Agilent ZORBAX Eclipse XDB-C18 column $(2.1 \times 150$ $\mathrm{mm} \times 3.5 \mu \mathrm{m}$ ) was used in this procedure. The oven was set at 25 ${ }^{\circ} \mathrm{C}$, and the volume of injection was $1 \mu \mathrm{L}$ containing $18 \mathrm{mg} / \mathrm{mL}$ in methanol. We used Shimadzu LC-MS 8030 with electrospray ion mass spectrometer (ESI-MS) to monitor the eluent under positive ion mode. Then, we scanned it from 100 to 1,000 mass/number of ions $(\mathrm{m} / \mathrm{z})$. ESI was performed by using skimmer $65 \mathrm{~V}$ and at a fragmentor voltage of $125 \mathrm{~V}$. Highly pure (99.99\%) nitrogen was used as drying gas at $10 \mathrm{~L} / \mathrm{min}$ flow rate, capillary temperature at $350{ }^{\circ} \mathrm{C}$, and nebulizer at $45 \mathrm{psi}$. The sample was injected to the 
mass detector by using the LC-30AD pump, Shimadzu CBM20A system controller, cooler, and CTO-30 column oven with the SIL-30AC autosampler. The results were validated by running the authentic standard compounds and referring to the literature as in the research of (16).

\section{Protein preparation and homology modeling}

The homology model for $\alpha_{2}$-adrenergic receptor was developed from the SWISS-MODEL server (22). Other software included in this study were Discovery Studio Visualizer 4.0 (Accelrys Software Inc, San Diego; http://www.accelrys.com), ACD/ChemSketch, (www.acdlabs.com), and AutoDock4 (23).

The protein sequence of $\alpha_{2}$-adrenergic receptor was selected from the universal protein source under the code no. P08913. The homology model of the protein was built at the SWISS-MODEL web server program. Initially, BLAST (24) was used to search for the target sequences against the primary amino acid sequence. Thereafter, the quality of the template was predicted from the target-template alignment features. Further, the best-quality templates were chosen for building the model.

\section{Molecular Docking}

$\mathrm{ACD} / \mathrm{ChemSketch}$ software was used to construct the chemical structures of major compounds in $M$. peregrina extract. These compounds were chrysoeriol 7-O-diglucoside, lupeol acetate, quercetin, and rutin. The compounds were drawn and saved as MOL files by ChemSketch software and then converted to PDB files. Ligand files in the PDB format were prepared by AutoDockTools. Each compound was opened separately, charges were added, and all the hydrogen atoms were merged. Molecular docking simulations of the compounds were performed by utilizing AutoDock 4.2. Kollman and Gasteiger charges were added to both proteins and plant compounds, respectively. A set of grid maps were created by using AutoGrid 4 (The Scripps Research Institute, San Diego, CA, USA). Then, a grid box was utilized to select the area of the protein structure to be mapped. The box size was set to 22.5, 22.5, and 22.5 $\AA$ ( $\mathrm{x}, \mathrm{y}$, and $\mathrm{z}$, respectively). Energy optimization and minimization was conducted by applying Lamarckian genetic algorithm in the docking simulation (16).

\section{Statistical analysis}

All data of this study passed the normality test (Shapiro-Wilk test). Brown-Forsythe and Welch One-Way analysis of variance tests for parametric analysis were used to examine the statistical difference between the groups. Version 6 of GraphPad Prism was chosen to perform the statistical analysis of this study.

\section{RESULTS}

In the writhing test, $200 \mathrm{mg} / \mathrm{kg}$ and $400 \mathrm{mg} / \mathrm{kg}$ of $M$. peregrina extract inhibited abdominal cramps by up to $55.97 \%$ and $88.00 \%$, respectively, as compared to inhibition percentage of $47.69 \%$ produced by $30 \mathrm{mg} / \mathrm{kg}$ of diclofenac sodium. Yohimbine antagonized the action of $M$. peregrina in the writhing test (Table 1). Additionally, the methanolic extract of $M$. peregrina reduced the time of paw-licking in the early and late phases of formalin test. high $(400 \mathrm{mg} / \mathrm{kg})$ and low $(200 \mathrm{mg} / \mathrm{kg})$ doses of M. peregrina extract exhibited inhibition percentages of $59.6 \%$ and $56.8 \%$, respectively, whereas $30 \mathrm{mg} / \mathrm{kg}$ diclofenac sodium produced an inhibition percentage of only $50.5 \%$ in the early phase of formalin test (Figure 1A). High (400 mg/kg) and low (200 mg/kg) doses of $M$. peregrina extract exhibited inhibition percentages of $50.1 \%$ and $65.5 \%$, respectively, as compared to an inhibition percentage of $48.4 \%$ achieved by $30 \mathrm{mg} / \mathrm{kg}$ diclofenac sodium in the late phase of formalin test (Figure 1B). This effect (in late phase only) was abrogated by yohimbine, but not by methysergide.

In the hot plate, but not tail-immersion test, a high dose of $M$. peregrina $(400 \mathrm{mg} / \mathrm{kg})$ extract increased the latency time after 30 minutes of its administration. Yohimbine antagonized the action of $M$. peregrina in the hot plate test (Table 2). By using LC-MS, 18 compounds were detected in the extract (Table 3). Chrysoeriol 7-O-diglucoside, lupeol acetate, quercetin, and rutin were the major compounds present in this extract.

SWISS-MODEL had generated around 531 templates, of which the top 50 filtered templates can be found in the supplementary material (Table S1). The homology model of $\alpha_{2}$-adrenergic receptor having a resolution of $1.96 \AA$ was validated by using the Ramachandran plot (Figure S1 in supplementary materials). Quality estimate of the homology model is presented in Figure S2 while predicted local similarity to target for the homology model is shown in Figure S3 in supplementary material. Figure 2 shows all the successfully docked plant constituents against the $\alpha_{2}$-adrenergic receptor model, and Table 4 shows the results of lowest binding energies .

The docking results showed a higher binding affinity for the compounds, namely chrysoeriol 7-O-diglucoside, quercetin, and rutin, with a low affinity for lupeol acetate. Further investigation of these compounds in the binding site have revealed that chrysoeriol 7-O-diglucoside, quercetin, and rutin participate in the hydrogen bond interactions as well as hydrophobic interactions within the binding site, whereas lupeol acetate participates only in the hydrophobic interactions (Figure 3).

TABLE 1. Writhing test results

\begin{tabular}{|c|c|c|c|c|c|c|}
\hline & $\begin{array}{l}\text { Control } \\
\text { (normal saline) }\end{array}$ & $\begin{array}{l}\text { M. peregrina } \\
(200 \mathrm{mg} / \mathrm{kg})\end{array}$ & $\begin{array}{l}\text { Yohimbine ( } 1 \mathrm{mg} / \\
\mathrm{kg}) \text { and } M . \text { peregrina } \\
(200 \mathrm{mg} / \mathrm{kg})\end{array}$ & $\begin{array}{l}\text { M. peregrina } \\
(400 \mathrm{mg} / \mathrm{kg})\end{array}$ & $\begin{array}{l}\text { Yohimbine }(1 \mathrm{mg} / \mathrm{kg}) \\
\text { and } \mathrm{M} . \text { peregrina } \\
(400 \mathrm{mg} / \mathrm{kg})\end{array}$ & $\begin{array}{l}\text { Diclofenac sodium } \\
(30 \mathrm{mg} / \mathrm{kg})\end{array}$ \\
\hline No of writhing & $49.00 \pm 3.16$ & $21.57 \pm 6.65^{*}$ & $54.80 \pm 7.79^{\#}$ & $5.88 \pm 4.22 *$ & $18.25 \pm 8.88^{£}$ & $25.63 \pm 7.78 *$ \\
\hline$\%$ inhibition & - & $55.97 \%$ & - & $88.00 \%$ & - & $47.69 \%$ \\
\hline P value & - & $\mathrm{p}<0.0001$ & $\mathrm{p}<0.0001$ & $\mathrm{p}<0.0001$ & $\mathrm{p}<0.05$ & $\mathrm{p}<0.0001$ \\
\hline
\end{tabular}

$\mathrm{n}=8$ values are mean \pm standard deviation of the mean, ${ }^{*}$ Significantly different from control, \#Significantly different from $M$. peregrina (200 mg/kg), ${ }^{£}$ Significantly different from $M$. peregrina $(400 \mathrm{mg} / \mathrm{kg})$ 
TABLE 2. Results of thermal antinociceptive tests: hot plate and tail flick tests

\begin{tabular}{llllll}
\hline & $\begin{array}{l}\text { Control } \\
\text { (normal saline) }\end{array}$ & $\begin{array}{l}\text { M. peregrina } \\
(200 \mathrm{mg} / \mathrm{kg})\end{array}$ & $\begin{array}{l}\text { M. peregrina } \\
(400 \mathrm{mg} / \mathrm{kg})\end{array}$ & $\begin{array}{l}\text { Yohimbine }(1 \mathrm{mg} / \mathrm{kg}) \text { and } \\
\text { M. peregrina } \\
(400 \mathrm{mg} / \mathrm{kg})\end{array}$ & $\begin{array}{l}\text { Diclofenac sodium } \\
(70 \mathrm{mg} / \mathrm{kg})\end{array}$ \\
\hline Latency time in hot plate test (sec.) & $9.23 \pm 1.63$ & $9.46 \pm 1.85$ & $\begin{array}{l}30.87 \pm 2.21^{*} \\
\mathrm{p}<0.0001\end{array}$ & $\begin{array}{l}22.03 \pm 5.35 \# \\
\mathrm{p}<0.0001\end{array}$ & $\begin{array}{l}22.84 \pm 2.99 * \\
\mathrm{p}<0.0001 \\
4.49 * \pm 0.63 \\
\mathrm{p}<0.001\end{array}$ \\
Latency time in tail flick test (sec.) & $2.92 \pm 0.53$ & $2.70 \pm 0.60$ & $2.34 \pm 0.60$ & - & \\
\hline $\mathrm{n}=14$ Values are mean \pm standard deviation of the mean, *Significantly different from control, "Significantly different from M. peregrina $(400 \mathrm{mg} / \mathrm{kg})$ &
\end{tabular}

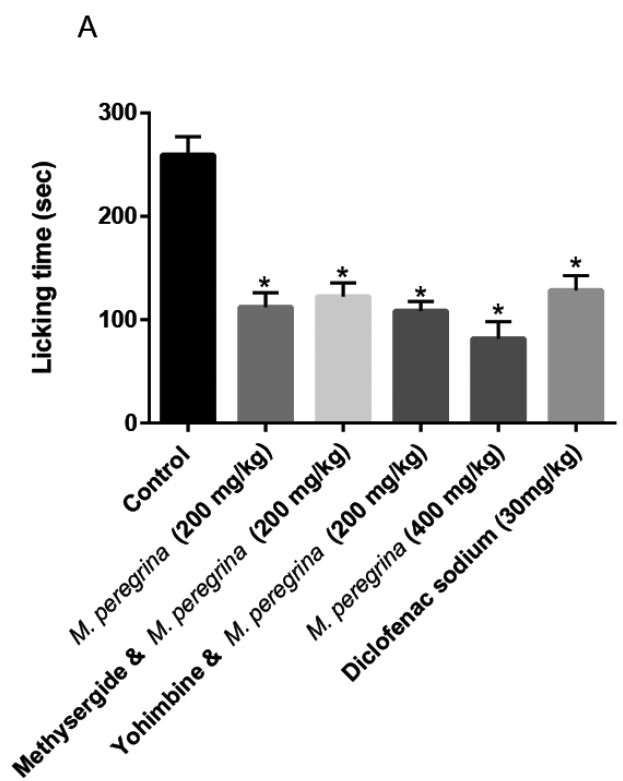

B

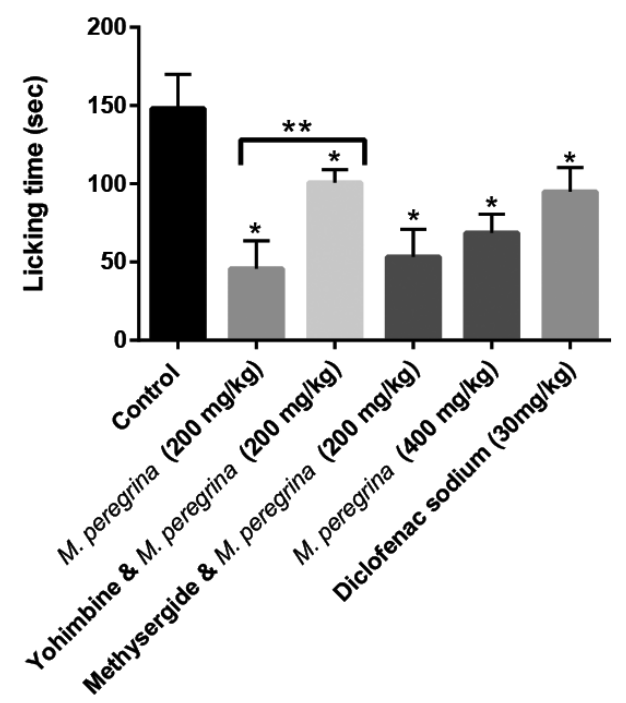

FIG. 1. a, b. Results of paw-licking test (formalin test). (a) Early phase (0-5 minutes after injection) (b) Late phase (25-30 minutes after injection).

${ }^{*}$ Significant difference from the control $(p<0.05),{ }^{* *} \mathrm{P}<0.05$ significantly different from M. peregrina $(200 \mathrm{mg} / \mathrm{kg}$ )

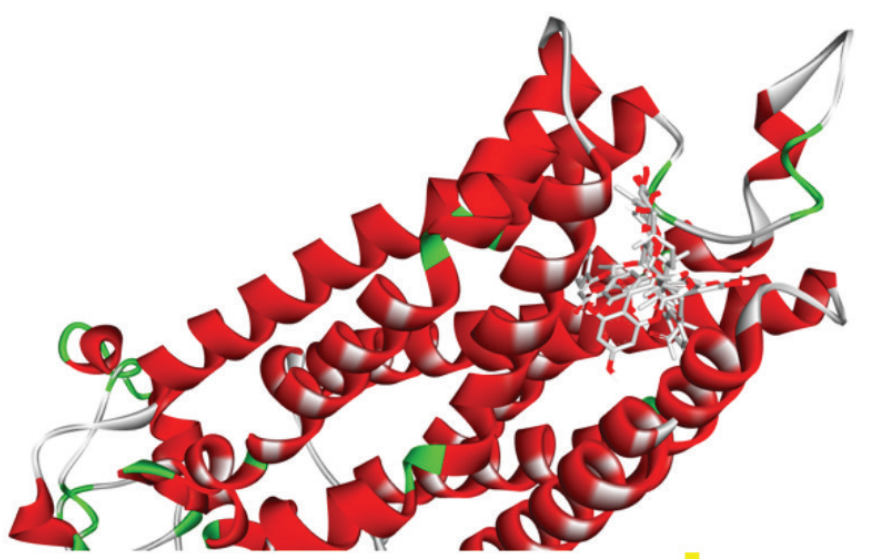

FIG. 2. Solid ribbon representation of $\alpha_{2}$-adrenergic receptor docked with the major compounds in $M$. peregrina extract, namely chrysoeriol 7-O-diglucoside, lupeol acetate, quercetin, and rutin, in the active site of the receptor.

TABLE 3. Chemical constituents of M. peregrina as detected by liquid chromatography-mass spectrometry

\begin{tabular}{llc}
\hline & Compound & $\%$ \\
\hline 1 & Apigenin & 0.88 \\
2 & Amyrin & 10.1 \\
3 & Beta-sitosterol-3-d-glucoside & 7.1 \\
4 & 2-Butyl isothiocyanate & 1.8 \\
5 & Chrysoeriol 7-O-diglucoside & 16.3 \\
6 & 5,5-Dimethyl-3-phenyl-1,3-oxazolidine-2-thione & 3.3 \\
7 & Lupeol acetate & 15.7 \\
8 & Methyl Glucosinolate & 1.8 \\
9 & 2-Methylpropyl isothiocyanate & 3.1 \\
10 & Neochlorogenic acid & 0.63 \\
11 & Niazirin & 0.68 \\
12 & Niazirinin & 1.8 \\
13 & 2-Propyl isothiocyanate & 2.2 \\
14 & Quercetin & 13.3 \\
15 & Rhamnetin & 1.05 \\
16 & 4(a-L Rhamnosyloxy) benzyl isothiocyanate & 0.97 \\
17 & Rutin & 11.4 \\
18 & Sitosterol & 6.3 \\
\hline
\end{tabular}



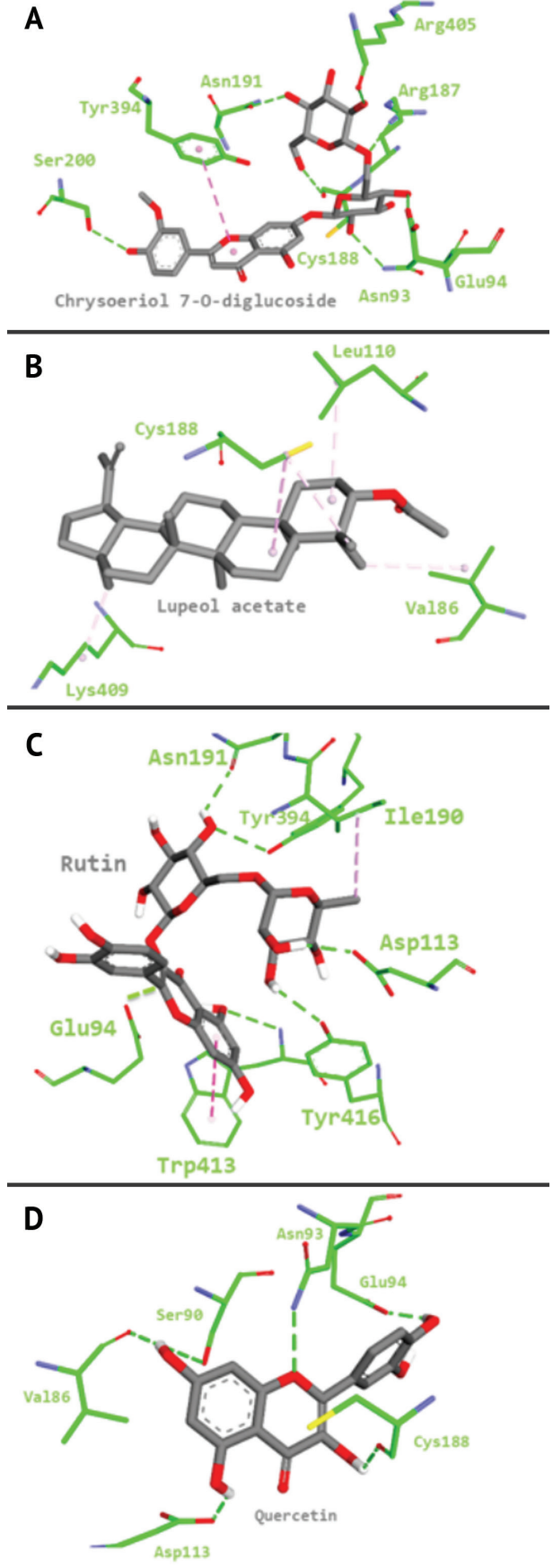

FIG. 3. a-d. Stick representation of a. chrysoeriol 7-O-diglucoside, b. lupeol acetate, c. rutin, and d. quercetin in the active site that forms hydrophobic (pink dots) interactions and hydrogen bond (green dots) with $\alpha_{2}$-adrenergic receptor.

\section{DISCUSSION}

In our study, $M$. peregrina exhibited marked analgesic properties induced by acetic acid in the writhing test. The percentage inhibition produced by $200 \mathrm{mg} / \mathrm{kg}$ and $400 \mathrm{mg} / \mathrm{kg}$ doses were $55.97 \%$ and $88 \%$, resprctively. Similar findings were obtained by Elbatran et al. (12) in which $113.4 \mathrm{mg} / \mathrm{kg}$ of $M$. peregrina decreased acetic acid-induced abdominal cramps by $70.7 \%$ in mice. Additionally, at the doses of 100 and $200 \mathrm{mg} / \mathrm{kg}$, M. oleifera extract significantly decreased writhes (25). This effect was not reversed by naloxone, thereby indicating a peripheral non-opioid mechanism of action (26). Bhattacharya et al. (27) also found that $M$. oleifera extract exhibited analgesic activity at 100,200, and $400 \mathrm{mg} / \mathrm{kg}$ in acetic acid-induced abdominal cramps in the writhing test, further showing percentage inhibitions of $32.21 \%, 59.71 \%$, and $78.61 \%$ of writhes, respectively, as compared with the control group (27). $M$. peregrina leaf extract demonstrated noticeable antinociception in the early and late phases of the formalin test. The administration of formalin causes three distinct periods with high licking behavior: an early phase lasting the first 5 minutes, and a late phase in the last 5 minutes after the injection. The early phase (neurogenic pain) is due to the direct activation of the primary afferent fibers. The late phase is known as inflammatory pain, thereby representing the effect in the primary afferents and central sensitization of spinal cord circuits secondary to the events that occurred during Phase I (28). The lowest dose of $M$. peregrina $(200 \mathrm{mg} / \mathrm{kg})$ was more active in the late phase than in the early phase and was more active than the higher dose $(400 \mathrm{mg} / \mathrm{kg})$. This can be explained by the non-specific effect of compounds in a higher dose with receptors that can block the interaction of active compounds with the receptor involved in the antinociceptive action. As per our knowledge, this study is the first one to report on the activity of $M$. peregrina in the formalin test. Similarly, $M$. oleifera leaves exhibited antinociceptive activity in the late phase $(25,26)$. Both polar and non-polar extracts of $M$. oleifera leaves were effective in both phases of formalin test. Due to the presence of central and peripheral actions of non-polar active compounds, the hexane extract was more effective than the ethanolic extract (29).

In the hot plate test, a high dose of $M$. peregrina $(400 \mathrm{mg} / \mathrm{kg})$ extract increased the latency time after 30 minutes of its administration. Similar results were reported by Elbatran et al. (12). In search for the mechanism of antinociceptive action of $M$. peregrine, the antagonists for adrenergic and 5-hydroxytryptamine type 2 (5HT2) serotonergic receptors were used in this study since previous studies suggested that the closely related species of $M$. oleifera interact with both dopaminergic and 5-HT2 serotonergic receptors (30). This study showed that yohimbine antagonized the action of

TABLE 4. The lowest binding energies obtained from AutoDock 4.2 for plant constituents against $\alpha_{2}$-adrenergic receptor and the interacting amino acids.

\begin{tabular}{|c|c|c|}
\hline Compound & Lowest binding energy (kcal/mol) & Interacting amino acids \\
\hline Chrysoeriol 7-O-diglucoside & -8.74 & Asn93, Glu94, Arg187, Cys188, Asn191, Ser200, Tyr394, Arg405. \\
\hline Lupeol acetate & -4.01 & Leu110, Val186, Cys188, Lys409. \\
\hline Quercetin & -7.88 & Ser90, Asn93, Glu94, Asp113, Val186. \\
\hline Rutin & -8.67 & Glu94, Asp113, Ile190, Asn191, Tyr394, Trp413, Tyr416. \\
\hline
\end{tabular}


M. peregrina in the hot plate test. As per our knowledge, this is the first report that shows the involvement of $\alpha_{2}$-adrenergic receptors in the action of $M$. peregrina. The related species of $M$. oleifera showed significant analgesic dose-dependent activity in the hot plate test (27). Study suggested that the effect of M. oleifera in the hot plate test is modulated at the central antinociceptive level via opioid receptors since the use of naloxone $(5 \mathrm{mg} / \mathrm{kg})$ reversed the effect of extract (26).

In the tail-immersion test, $M$. peregrina extract had no effect on the latency time of tail immersion after the administration of extract. In contrast, $M$. oleifera produced considerable antinociceptive action by enhancing tail-immersion latency period at 30 minutes (31). This could be explained by the presence of different phytoconstituents in the two species.

Both tail-immersion and hot plate tests are thermal acute pain tests. However, tail-immersion test works at the spinal level, whereas the hot plate test is a supraspinally controlled test (32). To the best of our knowledge, this study is the first one to report the lack of spinal reflexive action of $M$. peregrina.

Elbatran et al. (12) isolated four flavonoids from the aerial parts of $M$. peregrina and found that the major flavonoids are quercetin3-0-rutinoside (rutin), quercetin, chrysoeriol-7-0-rhamnoside, and 6,8,3,5-tetramethoxy apigenin. These flavonoids showed both analgesic and anti-inflammatory properties. Additionally, the aerial sections of $M$. peregrina have $\beta$-sitosterol-3-O-glucoside, $\beta$-sitosterol, $\alpha$-amyrin, $\beta$-amyrin, lupeol acetate, apigenin, 6-methoxy-acacetin-8-C- $\beta$-glucoside, neochlorogenic acid, rhamnetin, and rhamnetin-3-O-rutinoside (13). Lupeol acetate isolated from $M$. peregrine has a well-documented analgesic activity (33).

Depending on the previous results, we propose that the plant extract will interact with $\alpha_{2}$-adrenergic receptor to exert its analgesic activity. Thus, it will be useful to determine the active compounds that are responsible for this action. Due to the absence of complete $\alpha_{2}$-adrenergic receptor crystal structure, homology modeling is considered as an attractive technique for obtaining the structure. Such technique has proven to be an appropriate choice to obtain the useful 3D structure of the protein (34). Furthermore, molecular docking simulations have shown a good affinity of chrysoeriol 7-O-diglucoside, quercetin, and rutin toward the active site of the receptor.

In conclusion, our results suggest an interaction with $\alpha_{2}$-adrenergic receptor as a possible mechanism of analgesic action of $M$. peregrina. Depending on the molecular docking results, the activity of $M$. peregrina extract with $\alpha_{2}$-adrenergic receptor could be due to the binding of chrysoeriol 7-O-diglucoside, quercetin, and rutin compounds to the receptor.

Conflict of Interest: No conflict of interest was declared by the authors.

Financial Disclosure: This work was published with the support of Al-Ahliyya Amman University.

Supplementary: balkanmedicaljournal.org/uploads/pdf/supplementarymaterials.pdf

\section{REFERENCES}

1. Said-al Ahl HAH, Hikal WM and Mahmoud AA. Biological Activity of Moringa peregrina, A Review. Am J Food Sci Heal 2017;3:83-7.
2. Senthilkumar A, Karuvantevida N, Rastrelli L, Kurup SS, Cheruth AJ. Traditional Uses, Pharmacological Efficacy, and Phytochemistry of Moringa peregrina (Forssk.) Fiori. -A Review. Front Pharmacol 2018;9:465.

3. Al-Majali IS, Al-Oran SA, Hassuneh MR, Al-Qaralleh HN, Rayyan WA, Al-Thunibat OY, et al. Immunomodulatory effect of Moringa peregrina leaves, 1 ex vivo and in vivo study. Cent Eur J Immunol 2017;42:231-8.

4. Padayachee B and Baijnath H. An overview of the medicinal importance of Moringaceae. J Med Plants Res 2012;6:5831-9.

5. Asghari G, Palizban A, Bakhshaei B. Quantitative analysis of the nutritional components in leaves and seeds of the Persian Moringa peregrina (Forssk.) Fiori. Pharmacognosy Res 2015;7:242-8.

6. Osman $\mathrm{H}$ and Abohassan A. Morphological and analytical characterization of Moringa peregrina populations in western Saudi Arabia. Int J Theor Appl Sci 2012;4:174-84.

7. Sadraei H, Asghari G, Farahnaki F. Assessment of hydroalcoholic extract of seeds and leaves of Moringa peregrina on ileum spasm. Res Pharm Sci 2015;10:252-8.

8. El-Lamey TM. Ecophysiological responses of Moringaperegrina (Forssk.) Fiori growing naturally under different habitat conditions of Eastern Desert and Fieran Oasis, Egypt J Agric Vet Sc 2015;8:8-21.

9. Majali I, Althunibat OY, Qaralleh HN. Antimicrobial and Immunomodulatory activities of Moringa peregrine-Minireview. J Bas and Appl Res. 2015; 1: 55-61.

10. El Baky HA, El-Baroty GS. Characterization of Egyptian Moringa peregrine seed oil and its bioactivities. Int J Manage Sci Bus Res 2013;2:98-108.

11. Koheil MA, Hussein MA, Othman SM, El-Haddad A. Anti-inflammatory and antioxidant activities of Moringa peregrina seeds. Free Radical and Antioxidants 2011;1:49-61.

12. Elbatran SA, Abdel-Salam OM, Abdelshfeek KA, Nazif NM, Ismail SI, Hammouda FM. Phytochemical and pharmacological investigations on Moringa peregrina (Forssk) Fiori. Nat Prod Sci 2005;11:199-206.

13. El-Alfy TS, Ezzat SM, Hegazy AK, Amer AM, Kamel GM. Isolation of biologically active constituents from Moringa peregrina (Forssk.) Fiori.(family: Moringaceae) growing in Egypt. Pharmacogn Mag 2011;7:109-15.

14. Oyedepo T, Babarinde S, Ajayeoba T. Evaluation of anti-hyperlipidemic effect of aqueous leaves extract of Moringa oleifera in alloxan induced diabetic rats. Int $\mathrm{J}$ Biochem Res Rev 2013;3:162-70.

15. Safaeian L, Asghari G, Javanmard SH, Heidarinejad A. The effect of hydroalcoholic extract from the leaves of Moringa peregrina (Forssk.) Fiori. on blood pressure and oxidative status in dexamethasone-induced hypertensive rats. Adv Biomed Res 2015;4:101.

16. Alzoubi KH, Rawashdeh NQ, Khabour OF, El-Elimat T, Albataineh H, Al-Zghool $\mathrm{HM}$, et al. Evaluation of the effect of Moringa peregrina extract on learning and memory: Role of oxidative stress. J Mol Neurosci 2017;63:355-63.

17. Zimmermann M. Ethical guidelines for investigations of experimental pain in conscious animals. Pain 1983;16:109-10.

18. Jaffal SM, Abbas MA. Antinociceptive Action of Ononis spinosa leaf extract in mouse pain models. Acta Pol Pharm 2019;76:299-304.

19. Rodrigues AL, Rosa JM, Gadotti VM, Goulart EC, Santos MM, Silva AV, et al. Antidepressant-like and antinociceptive-like actions of 4-(4'-chlorophenyl)-6-(4 "-methylphenyl)-2-hydrazinepyrimidine Mannich base in mice. Pharmacol Biochem Behav 2005;82:156-62.

20. de Lima FO, Alves V, Barbosa Filho JM, Almeida JR, Rodrigues LC, Soares MB et al. Antinociceptive effect of lupeol: evidence for a role of cytokines inhibition. Phytother Res 2013;27:1557-63.

21. Koster R, editor Acetic acid for analgesic screening. Fed Proc 1959;18:418-20.

22. Waterhouse A, Bertoni M, Bienert S, Studer G, Tauriello G, Gumienny R, et al. SWISS-MODEL: homology modelling of protein structures and complexes. Nucleic Acids Res 2018;46:296-303.

23. Morris GM, Huey R, Lindstrom W, Sanner MF, Belew RK, Goodsell DS, et al AutoDock4 and AutoDockTools4: Automated docking with selective receptor flexibility. J Comput Chem 2009;30:2785-91.

24. Camacho C, Coulouris G, Avagyan V, Ma N, Papadopoulos J, Bealer K, et al BLAST+: architecture and applications. BMC Bioinformatics 2009;10:421.

25. Adedapo AA, Falayi OO, Oyagbemi AA. Evaluation of the analgesic, antiinflammatory, anti-oxidant, phytochemical and toxicological properties of the methanolic leaf extract of commercially processed Moringa oleifera in some laboratory animals. J Basic Clin Physiol Pharmacol 2015;26:491-9. 
26. Sulaiman MR, Zakaria ZA, Bujarimin AS, Somchit MN, Israf DA, Moin S. Evaluation of moringa oleifera aqueous extract for antinociceptive and anti-inflammatory activities in animal models. Pharm Biol 2008;46:838-45.

27. Bhattacharya A, Agrawal D, Sahu PK, Kumar S, Mishra SS, Patnaik S. Analgesic effect of ethanolic leaf extract of Moringa oleifera on albino mice. Indian J Pain 2014;28:89-94.

28. Hassani FV, Rezaee R, Sazegara H, Hashemzaei M, Shirani K, Karimi G. Effects of silymarin on neuropathic pain and formalin-induced nociception in mice. Iran J Basic Med Sci 2015;18:715-20.

29. Martínez-González CL, Martínez L, Martínez-Ortiz EJ, González-Trujano ME, Déciga-Campos M, Ventura-Martínez R, et al. Moringa oleifera, a species with potential analgesic and anti-inflammatory activities. Biomed Pharmacother $2017 ; 87: 482-8$
30. Upadhye KP, Rangari VD, Mathur VB. Antimigraine activity study of Moringa oleifera leaf juice. International Journal of Green Pharmacy 2012;6:204-7.

31. Bhairi RS, Rasheeduddin M, Nadithe LR. Comparative Study of Analgesic Effect of Moringa Oleifera with Lornoxicam in Rats. J Cont Med A Dent 2015;3:44-7.

32. Singh P, Kongara K, Harding D, Ward N, Dukkipati VSR, Johnson C, et al Comparison of electroencephalographic changes in response to acute electrical and thermal stimuli with the tail immersion and hot plate test in rats administered with opiorphin. BMC Neurol 2018;18:43.

33. Chen YF, Ching C, Wu TS, Wu CR, Hsieh WT, Tsai HY. Balanophora spicata and lupeol acetate possess antinociceptive and anti-inflammatory activities in vivo and in vitro. Evid-Based Compl Altern Med 2012;2012:371273.

34. Cavasotto CN, Phatak SS. Homology modeling in drug discovery: current trends and applications. Drug Discov Today 2009;14:676-83. 